\title{
High-throughput fluorescent sequencing of biomolecules within their cellular environment
}

\begin{tabular}{|c|c|c|}
\hline $\begin{array}{l}\text { Understanding the molecular } \\
\text { diversity within healthy or } \\
\text { diseased tissues is crucial for } \\
\text { the diagnosis and treatment of } \\
\text { diseases and for gaining a better } \\
\text { understanding of fundamental } \\
\text { biological processes. Biological } \\
\text { tissues contain thousands } \\
\text { of different molecules, yet } \\
\text { conventional staining looks at } \\
\text { only a few at a time because it } \\
\text { relies on a limited number of } \\
\text { dyes. Prof George Church and } \\
\text { Dr Richie Kohman from the Wyss } \\
\text { Institute at Harvard Medical } \\
\text { School have pioneered a number } \\
\text { of techniques that use synthetic } \\
\text { biology to image a multitude } \\
\text { of molecular targets directly on } \\
\text { unaltered biological samples. }\end{array}$ & $\begin{array}{l}\text { he study of biological tissues } \\
\text { traditionally ynvolves the suse of } \\
\text { staining techniques that rely on } \\
\text { a limited number of dyes, only allowing } \\
\text { the handling of a few molecules at any } \\
\text { one time. This limits the diagnostic } \\
\text { potential of traditional techniques and } \\
\text { our understanding of how thousands of } \\
\text { molecules interact within healthy and } \\
\text { diseased tissues. Furthermore, traditional } \\
\text { techniques of genome sequencing are } \\
\text { able to provide information about the } \\
\text { genes present; however, they involve } \\
\text { protocols that cause the physical } \\
\text { disrruption of cells and tissues, } \\
\text { meaning that crucial information } \\
\text { about the location of each mRNA } \\
\text { within the cell is lost. } \\
\text { In order to advance our knowledge } \\
\text { and understanding of systems biology, } \\
\text { the challenge will be to devise the use } \\
\text { of complementing techniques that } \\
\text { can blend the deciphering power of } \\
\text { next-generation sequencing with the } \\
\text { high-resolution potential of fluorescence } \\
\text { microscopy. There is also a need for } \\
\text { diagnostic techniques that can spot } \\
\text { subtle changes to the chemical } \\
\text { environment in specific regions within } \\
\text { the cellular architecture in order to enable } \\
\text { early diagnosis and prevent late-stage } \\
\text { onset of a number of diseases. } \\
\text { Prof George Church and Dr Richie } \\
\text { Kohman from the Wyss Institute } \\
\text { laboratory at Harvard Medical School } \\
\text { have pioneered and perfected a range } \\
\text { of techniques, blending them into a } \\
\text { unified approach that is capable of } \\
\text { imaging a multitude of molecular targets } \\
\text { simultaneousli without affecting the } \\
\text { celllular integrity of their samples. The } \\
\text { result is a technique called Fluorescent } \\
\text { in situ sequencing (FISSEQ). In situ is } \\
\text { latin for 'in place', meaning that the }\end{array}$ & $\begin{array}{l}\text { detection technique works within the } \\
\text { unaltered spatial environment of the cell. } \\
\text { Genes are expressed into proteins } \\
\text { through the intervention of messenger } \\
\text { RNAs (mRNAs) that are positioned } \\
\text { strategically within the cellular } \\
\text { compartments. Therefore, it is important } \\
\text { to not only determine the sequence of } \\
\text { mRNAs, but crucially also their position. } \\
\text { The idea behind FISSEQ is simple. Each } \\
\text { mRNA is enzymaticallly converted into a } \\
\text { matching strand of DNA, which is then } \\
\text { multiplied several times to create tiny } \\
\text { balls of replica DNA, still attached to } \\
\text { the original spot. Then, four fluorescent } \\
\text { dyes, one for each DNA base, enable } \\
\text { the detection of the DNA's exact } \\
\text { sequence through a series of flashing } \\
\text { colours, all under a microscope. } \\
\text { ADAPTING FISSEO FOR } \\
\text { THE STUDY OF PROTEOMES } \\
\text { FISSEQ was first developed to locate } \\
\text { thousands of messenger RNAs all at } \\
\text { once within intact cells. The technique } \\
\text { was then modified to also allow the } \\
\text { detection of proteins by inserting unique } \\
\text { DNA tags on them that can be detected } \\
\text { by the sequencing method described } \\
\text { above. This can be achieved br bsing } \\
\text { oligonucleotide-conjugate antibodies } \\
\text { that are bound to their target proteins. } \\
\text { The conjugated nucleotide tags are then } \\
\text { sequenced in unaltered samples through } \\
\text { FISSEQ. The computer-designed } \\
\text { oligonucleotide chosen as tags are } \\
\text { synthesised and uniquely assigned to } \\
\text { each antibody, acting as barcodes that } \\
\text { can be detected in multiple imaging } \\
\text { rounds. The team has shown that their } \\
\text { barcoding technique worked in whole } \\
\text { mouse brain slices. The technique is } \\
\text { straightforward and will enable the } \\
\text { simultaneous identification of numerous } \\
\text { barcoded proteins. With only three }\end{array}$ \\
\hline
\end{tabular}

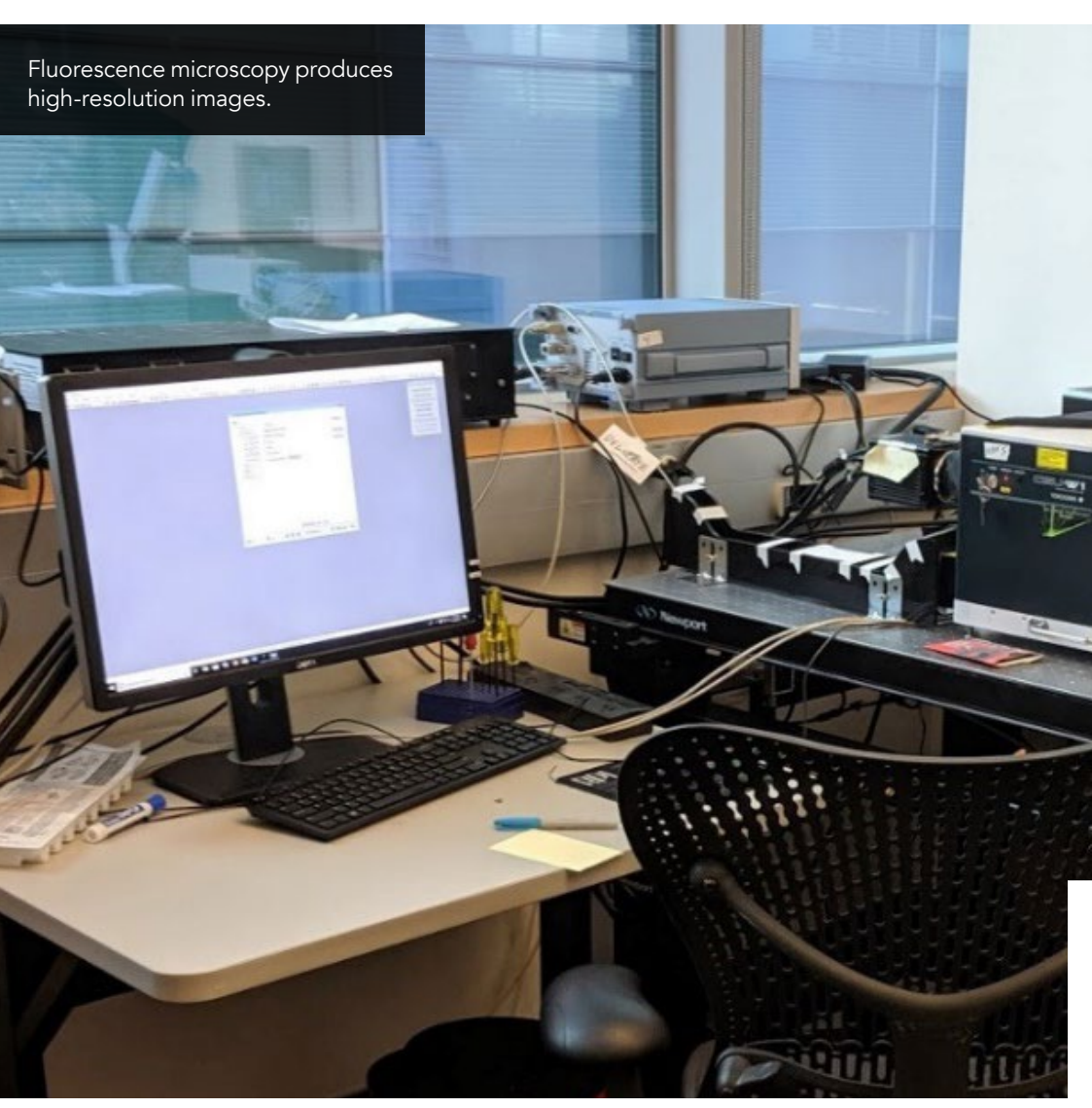

FISSEO will revolutionise the way in which we understand biology.

rounds of sequencing, this approach would all ow the identification of 64 targets in parallel. In comparison, using two traditional fluorescent colour dyes
as hybridisation tags would only be able as hybridisation tags would
to detect 6 unique targets.

Through all of the variations of FISSEQ, users will someday be abs to visulise hundreds or thas bands of proteins simultaneously giving important insight into their function within the cellular architecture. Interestingly the techriq allows researchers to spot subtle differences in the expression of proteins in otherwise seemingly healthy tissues. The technique could, for example, be employed to identify dangerous mutations that could lead to cancer early on or could offer insight into the progression of debiltating conditions such as Alzheimer's Disease. The latest developments of the technique allow it to yield nanoscale resolution imaging compaxpression in subcellitar nanoscale resolution maps of RNAs thoughor the spins and decates in

\section{'WRITING IN' SYNTHETIC} MOLECULAR SIGNATURES

FISSEQ will revolutionise the way in which we understand biotionise the way in which not limited to the investigation of naturat tissues. The team at the Wyss Institute is also making efforts to use synthetic biology to engineer biological samples to contain specific molecular signatures, effectively 'writing in' genetic information into complex living systems.

Tailoring the timing and location of these genetic signatures allows the study of processes that were previously challenging to investigate. For example, in mice, cells can be genetically modified in such a way that they keep a chemical scientists to track the complex series of
Prof Church and Dr Kohman demonstrated that they could obtain

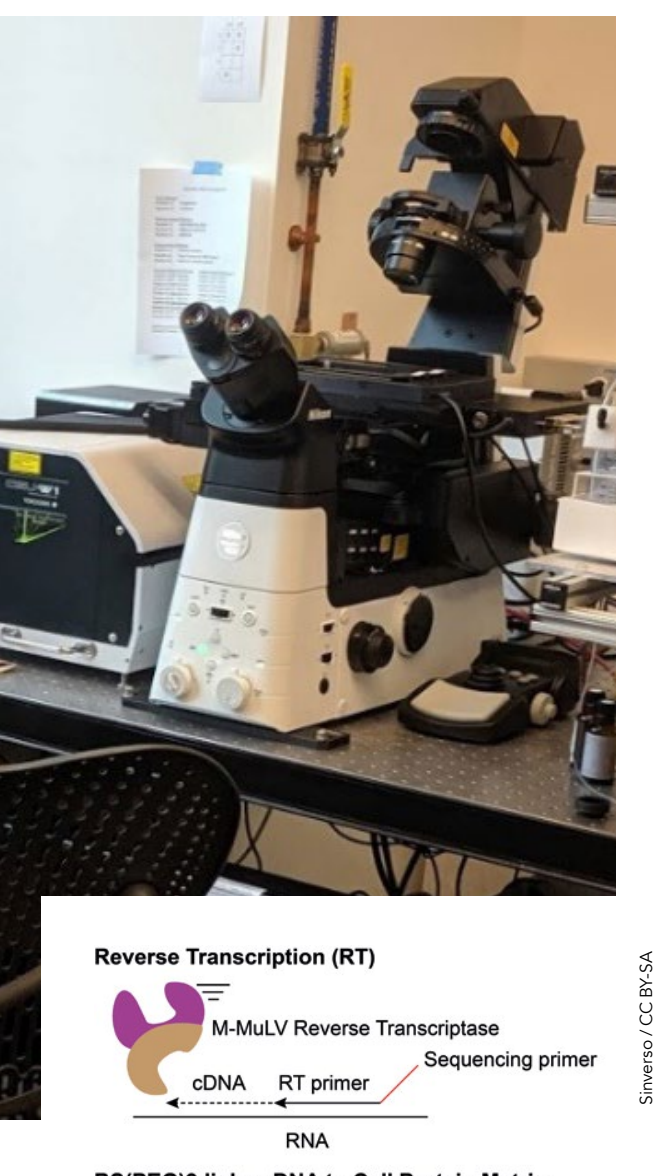

S(PEG)9 links cDNA to Cell Protein Matrix Cell Protein Matrix

$\frac{\text { BS(PEG) }\left.\right|_{\mathrm{CDNA}} \mathrm{RT} \text { primer }}{\text { RNA Sequencing primer }}$ Circularize CDNA template RT primer Copy cDNA many times Copy cDNA many tim

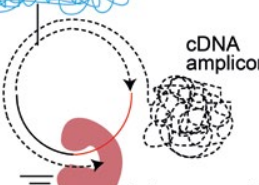
Sequence the CDNA amplicons in the coll Cross-linked cDNA amplicons FISSEO schematic. A tagged random hexamer
primer is used to prime M-MuLV reverse transcriptase to generate aminoallyl dUTP.
modified cDNA fragments in fixed cells or tissues. BS(PEG) 9 permanenenty cross-links
the modified CDNA and the cellular protein matrix. After cDNA circularization, Phiz29 DNA
polymerase generates cDNA amplicon. The cross-linked amplicons i in the $3 \mathrm{D}$ in in situ RNA
within the cell is sequenced 


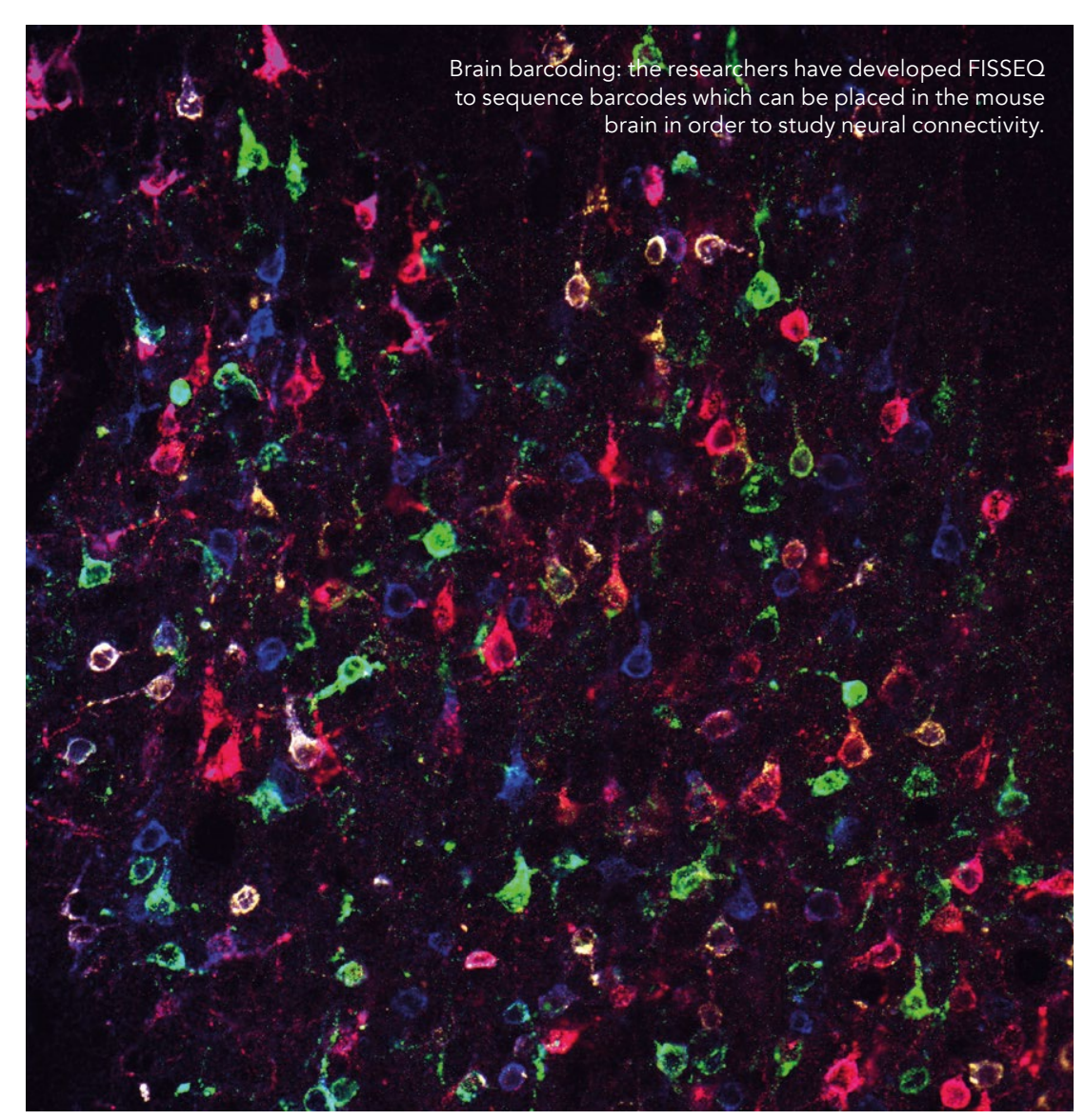

Through all of the variations of FISSEQ, users will someday be able to visualise hundreds or thousands of proteins simultaneously within the cellular architecture.

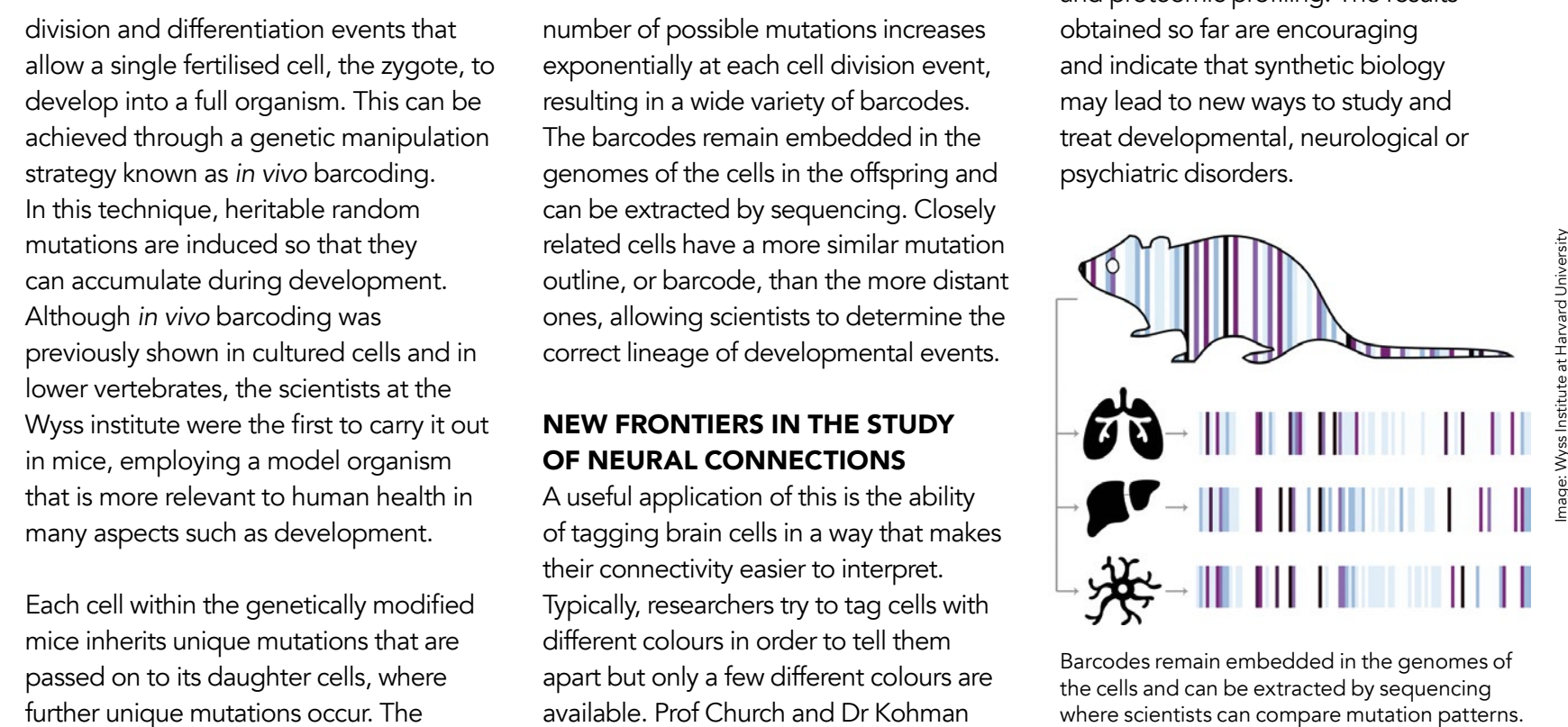

reasoned that if colours were replaced by barcodes, every cell in the brain could be of barcodes is virtually unlimited. First, the team has developed a powe ful version of FISSEQ to sequence barcodes which can be placed in the mouse brain with engineered viruses. Next, they are working to better position the barcodes so that they reside where the cells connect. Prof Church and Dr Kohman believe that using this sequencing approach to establishing neural connections will overcome many of the 政 ty on aligning thousands of thin section study neural connectivity is compatib connectivity can be investigated whit imultan proteins and RNA within the samples.

A REVOLUTION IN OUR FUTURE UNDERSTANDING OF LIFE SCIENCES

Prof Church and Dr Kohman of the Wyss Institute believe that the combination of approaches to write and read genetic sequences in complex mammals will be crucial for future breakthroughs in medicine and

simultaneously detect hundreds or Within the of molecules in single cells dran the native tissue organisation will advance research in life sciences, drug providing the dicate that synthetic biology

where scientists can compare mutation patterns together. Additionally, his approach to development, and clinical diagnostics,

\section{Behind the Research}

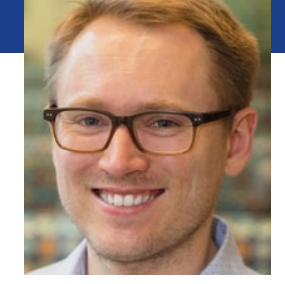

Dr Richie Kohman

Prof George Church

Richie Kohman: E: richie.kohman@wyss.harvard.edu E: rekohman@gmail.com T: +12177143044 W: https://richiekohman.com/ W: https://www.researchgate.net/profile/Richie Kohman W. https://www.linkedin.com/in/RichieKohman

\section{Research Objectives}

Prof George Church and Dr Richie Kohman are developing techniques to image a multitude of molecular targets by applying next-generation sequencing (NGS).

\section{Detail}

Wyss Institute for Biologically Inspired Engineering at Harvard University
3 Blackfan Circle, Boston, MA 02115, USA

Richie Kohman is the Lead of the Synthetic Biology Platform at the Wys Institute at Harvard University. He at the University of Champaign and was a postdoctor fellow in the Department of Biomedical

\section{Engineering at Boston University and an affiliate of the MIT Media Lab. \\ George Church is the Robert Winthrop Professor of Genetics at Harvard Medical School and Professor of Health Sciences and Technology at Harvard and MIT. He is a founding member of the Wyss Institute for Biologically Inspired Engineering and is sequencing, synthetic biology, and genome engineering.}

\section{References}

- Turczyk, B.M., Busby, M., Martin, A.L., Daugharthy, E.R. Myung, D., Terry, R.C., Inverso, S.A., Kohman, R.E., and Church, G.M. (2020). Spatial Sequencing: A Perspective, Journal of Biomolecular Techniques, 31(2), 44-46.

- Kohman R.E. and Church, G.M. (2020). Fluorescent in situ sequencing of DNA barcoded antibodies. bioRxiv. Available at: https://doi.org/10.1101/2020.04.27.06062

- Alon, S., et al. (2020) Expansion Sequencing: Spatially Precise In Situ Transcriptomics in Intact org/10.1101/2020.05.13.094268 - Kalhor, R., Kalhor, K., Mejia, L., Leeper, K., Graveline,
A., Mali, P., and Church, G.M. (2018). Developmental barcoding of whole mouse via homing CRISPR. Science, 361(6405), eaat9804. Available at: https://www.doi. org/10.1126/science.aat9804

Chen, X., Sun, Y.C., Church, G.M., Lee, J.H., and Zador, A.M. (2018). Efficient in situ barcode sequencing using
padlock probe-based BaristaSeg. Nucleic Acids Research 46(4), e22. Available at: https://doi.org/10.1093/nat/ gkx1206

\section{Personal Response}

Do you plan to employ 'in vivo' barcoding to such as autism, depression or epilepsy?

II Yes, we have a great interest in gaining a better understanding of neurological and psychiatric disorders. Much is currently unknown about these conditions, making it challenging to come up with effective treatments and associated with altered brain connectivity; hownewn to be difficult to understand what role this plays because there is currently no way to study how the brain is connected at both high resolution and over large distances. We believe that a combination of analysing in vivo barcodes in conjunction will ultimate lead to the best understanding of pathological dysfunction in the brain.

wyss institute 